Jurnal Medicoeticolegal dan Manajemen Rumah Sakit, 5 (2): 93-106, Juli 2016

Website: http://journal.umy.ac.id/index.php/mrs

DOI: $10.18196 / \mathrm{jmmr} .5112$.

\title{
Pemahaman Implementasi Rencana Strategi Bisnis Rumah Sakit PKU Muhammadiyah Petanahan
}

\author{
Andika Purwita Aji ${ }^{1 *}$ \& Heru Kurnianto Tjahjono ${ }^{2}$ \\ *Penulis Korespondensi: ndika.dr@gmail.com \\ ${ }^{1}$ Rumah Sakit PKU Muhammadiyah Petanahan \\ ${ }^{2}$ Magister Manajemen Rumah Sakit Universitas Muhammadiyah Yogyakarta

\begin{tabular}{l}
\hline $\boldsymbol{I N D}$ EXI $\boldsymbol{N} \boldsymbol{G}$ \\
\hline Keywords: \\
Strategy business \\
planning, \\
Implementation, and \\
Hospital.
\end{tabular}

\begin{tabular}{l}
\hline A B S T R A C T \\
\hline Managers Hospital admit that Strategy planning is important forces management, but this Strategy \\
planning still become problem because some obstacles that faced to manage it well and exact. Basic \\
obstacle relate to human resource obstacle that very determine quality and axact strategy planning. \\
There are some obstacles that make strategy planning doesn't yet optimal as important forces \\
management that very needed on face change environment that change quickly. Key factor success \\
strategy planning is formation systematic strategy, implementation strategy that effective, and \\
restrain even follow up from Implementation (Brenes, et al.2008). According to view of resource, the \\
resource based view of the firm(RBV), Resource that had Hospital can become source that enable to \\
approximating and implementation that can increase efficiency and effectiveness of Hospital (Barney, \\
1991). Resource and capability determine factor Hospital strategy and profitability determiner factor \\
Hospital (Grant 1997; Collis\&Montgomery, 1998). Kind of Research that used in this Research is \\
Qualitative, Populations are head room Nurse, Midwife and all Components that support data \\
Research. Strategy business planning Components Hospital generally has prepared well but doesn't \\
socialised yet to employee in Muhammadiyah Hospital of Petanahan. Suggestion do socialiszation \\
and Implementation workshop Business planning Strategy Hospital.
\end{tabular}

(C) 2016 JMMR. All rights reserved

Article history: received 25 Jul 2016; revised 19 Okt 2016; accepted 25 Nov 2016

\section{PENDAHULUAN}

Rumah Sakit (RS), sebagai industri jasa kesehatan tidak dapat terhindar dari perubahan. Perubahan lingkungan yang begitu kompleks, membawa perubahan pandangan stakeholder rumah sakit dan selanjutnya berdampak pada perubahan paradigma dalam pelayanan jasa Rumah Sakit (RS) di Indonesia (Assauri, 2004)

Perencanaan strategik memungkin kan rumah sakit untuk mengantisipasi kondisi yang selalu berubahubah (Taylor, 1997; Jauch \& Glueck, 2004) dan me nyediakan peta perjalanan dan arah yang dituju serta cara mencapainya (Shapiro, 2009). Rumah sakit yang terlibat dalam perencanaan strategik cenderung lebih berkembang di tengah persaingan yang berat dibandingkan yang tidak (Athiyaman \& Robertson, 1995).Perencanaan strategik merupakan perangkat manajemen penting yang dapat membantu organisasi dalam melakukan tugasnya dengan lebih baik. Memfasilitasi pengembangan strategi dan implementasi, serta organisasi menjadi lebih sensitif terhadap kebutuhan pe langgan dan pasar (Bonn \& Christodoulou, 1996;Obeng\& Ugboro 2008). Perencanaan strategik (strategic planning) vital bagi organisasi dalam mempertahankan ke langsungan hidupnya (Robbins \& Coulter, 2007; Jauch \& Glueck, 2004; Wheleen \& Hunger, 2004). Baldrige National Quality Program (2008), menetapkan strategic planning sebagai salah satu komponen dari sistem untuk mencapai kinerja unggul.Perencanaan strategik terbukti berpengaruh nyata terhadap kinerja organisasi (Phillips, 1996; Brews \& Purohit, 2007; Rudd et al., 2008).

Para pimpinan RS mengakui bahwa perencanaan strategik merupakan pe rangkat manajemen penting, namun, perencanaan strategik ini masih menjadi masalah karena berbagai kendala yang dihadapi untuk dapat menyusunnya dengan baik dan tepat. Kendala mendasar menyangkut sumber daya manusia (SDM) dan kendala data/informasi yang sangat menentukan kualitas dan ketepatan rencana strategik (renstra). Adanya berbagai kendala tersebut membuat perencanaan strategik belum optimal sebagai perangkat manajemen penting yang sangat dibutuhkan dalam menghadapi perubahan lingkungan yang berubah demikian cepat. Faktor sukses kunci penerapan perencanaan strategik adalah proses formulasi strategi yang sistematis, pelaksanaan atau implementasi strategi yang efektif, dan pengendalian serta tindak lanjut dari implementasi (Brenes, 
et al. 2008). Menurut pandangan berbasis sumber daya, the resource based view of the firm (RBV), sumber daya yang dimiliki rumah sakit dapat menjadi sumber yang memungkinkan untuk memperkira kan dan mengimplementasikan strategi yang dapat meningkatkan efisiensi dan efektivitas rumah sakit (Barney, 1991). Sumber daya dan kapabilitas rumah sakit merupakan prinsip dasar strategi dan faktor penentu profitabilitas rumah sakit (Grant, 1997; Collis \& Montgomery,1998).

Berdasarkan latar belakang yang telah diuraikan sebelumnya, peneliti tertarik untuk melakukan pengkajian tentang pemahaman implementasi rencana strategi bisnis RS PKU Muhammadiyah Petanahan Kebumen.

\section{METODE PENELITIAN}

Jenis penelitian digunakan dalam penelitian ini adalah kualitatif. Penelitian kualitatif merupakan suatu paradigma penelitian untuk mendeskripsikan peristiwa, perilaku orang atau suatu keadaan pada tempat tertentu secara rinci dan mendalam dalam bentuk narasi (Satori, 2009).

Metode yang digunakan dalam penelitian ini adalah metode penelitian naturalistik kuatitatif. Karakteristik penelitian kualitatif menurut Bogdan dan Biklen (1982) adalah seperti berikut: (1) Qualitative research has the natural setting as the direct source of data and researcher is the key instrument; (2) Qualitative research is descriptive. The data collected is in the form of words of picture rather than numbers; (3) Qualitative research are concerned with process rather than simply with outcomes or products; (4) Qualitative researchs tend to analyze their data inductively; and (5) "Meaning" is essensial to the qualitativ approach (Bogdan dan Bikien, 1982:27)

Nasution (1968) memberikan ciri-ciri penelitian naturalistik adalah sumber data ialah situasi yang wajar atau natural setting, peneliti sebagai instrumen penelitian, sangat deskriptif, mementingkan proses maupun produk, mencari makna, mengutamakan data langsung atau first hand, adanya triangulasi, menonjolkan rincian kontekstual, subyek yang diteliti dipandang berkedudukan sama dengan peneliti, mengutamakan perspekti emic, verifikasi, sampling yang purposif, menggunakan audit trail partisipasi tanpa mengganggu, dan mengadakan analisis sejak awal penelitian. Dalam penelitian mi digunakan ciri penelitian baik yang diberikan oleh Bogdan dan Bikien maupun Nasution. Dalam penelitian ini, peneliti ingin menggambarkan rencana strategis bisnis RS PKU Muhammadiyah Petanahan untuk dapat bersaing dengan rumah sakit sejenis lainnya. Lokasi penelitian berada di RS PKU Muhammadiyah Petanahan Kebumen. Penelitian akan dilakukan selama Bulan Oktober 2014. Menurut Maleong (2004) data yang dibutuhkan dalam penelitian kualitatif adalah berupa kata-kata atau tindakan orang-orang yang diamati atau diwawancarai. Data-data tersebut dicatat melalui perekaman audio tape, pengambilan foto, catatan lapangan. tersebut maka dideskripsikan dalam bentuk transkrip wawancara. Unsur manusia merupakan instrumen kunci, yaitu penelitian yang terlibat langsung dalam observasi partisipasi, yang menjadi informan adalah karyawan RS PKU Muhammadiyah Petanahan mulai dari Direktur, Kepada Ruang, Perawat, Bidan dan semua komponen yang mendukung data penelitian. Unsur non manusia sebagai data pendukung penelitian.

Penentuan sampel dalam penelitian kualitatif sangat tepat jika didasarkan pada tujuan atau masalah penelitian, yang menggunakan pertimbangan-pertimbangan dari peneliti itu sendiri, dalam rangka memperoleh ketepatan dan kecukupan informasi yang dibutuhkan sesuai dengan tujuan atau masalah yang dikaji sehingga penarikan sampel yang tepat adalah penarikan sampel berdasarkan tujuan atau purposive sampling (Satori, 2009). Perolehan data penelitian yang luas serta mendalam, maka upaya yang dilakukan melalui:

Menurut Satori (2009:52), observasi partisipatif merupakan seperangkat strategi yang tujuannya adalah untuk mendapatkan suatu keakraban yang dekat dan mendalam dengan satu kelompok individu dan perilaku mereka melalui satu keterlibatan yang intensif dengan orang di lingkungan alami mereka. Dalam penelitian ini, peneliti menempatkan sejumlah tujuan dan menempatkan diri sebagai bagian dari obyek yang sedang diteliti. Dalam melakukan wawancara, dibuat pedoman yang dijadikan acuan dan instrumen wawancara yang dilakukan bersifat terbuka, terstruktur dengan pedoman. Selama melakukan observasi, peneliti mengambil data dengan menggunakan lembar observasi dan lembar pedoman wawancara.

Rumah sakit yang dimaksud dalam penelitian ini adalah RS PKU Muhammadiyah Petanahan merupakan rumah sakit swasta yang terletak di Jalan Daendels Km 1 Ds Munggu, Kec. Petanahan, Kab. Kebumen, Jawa Tengah. Jalannya penelitian ini melalui beberapa tahap yaitu: (1) Tahap persiapan penelitian diawali dengan mengurus surat ijin ke bagian akademik Universitas Muhammadiyah Yogyakarta dan bagian terkait untuk melakukan studi pendahuluan. (2) Melakukan penyusunan pedoman wawancara mendalam (In-Depth Interview). Tahap ini peneliti melakukan penyusunan proposal. Penyusunan proposal, seminar proposal, dilanjutkan dengan perbaikan proposal, sampai dengan proposal disetujui dan disahkan. (3) Menentukan responden untuk wawancara mendalam. (4) Mengadakan wawancara mendalam dengan sebelumnya menjalin keakraban dengan responden agar tercipta suasana yang nyaman antara peneliti dan responden. (5) Mengumpulkan hasil wawancara mendalam lalu melakukan 
pengolahan data. Untuk memiliki data yang mempunyai kepercayaan tinggi maka dilakukan triangulasi data. (6) Tahap akhir penelitian dilakukan penyajian hasil analisa dan penyusunan pembahasan tentang hasil penelitian dilengkapi dengan kesimpulan penelitian serta saran atau rekomendasi tindak lanjut dari hasil penelitian.

Menurut Miles dan Huberman (1992) dalam Ircham (2008) langkah-langkah dalam analisis data kualitatif meliputi pengumpulan data, reduksi data, penyajian data, dan penarikan kesimpulan (verifikasi), hubungan langkahlangkah tersebut bersifat interaktif yang dapat digambarkan seperti gambar berikut: Teknik pengumpulan data yang digunakan adalah observasi, wawancara mendalam, dan dokumentasi. Alat yang digunakan mengumpulkan data di tempat penelitian antara lain panduan wawancara, alat tulis, tape recorder, dan kamera foto.

Perincian data dari observasi dan wawancara serta dokumentasi cukup banyak. Data tersebut akan semakin banyak apabila waktu penelitian bertambah. Berbagai data tersebut ada yang sama, ada yang berbeda, ada yang penting dan ada yang tidak penting. Dalam tahap reduksi ini peneliti mengkategorikan data mana yang lebih penting, mana yang bermakna, dan mana yang tidak penting. Data yang tidak penting dibuang. Dengan reduksi data maka, gambaran hasil penelitian akan lebih jelas.

Langkah-langkah reduksi data adalah sebagai berikut:

Melakukan transkrip yang berisi informasi deskriptif mengenai data yang diperoleh, yang ditulis menurut apa yang dikatakan oleh responden. Editing dengan cara memeriksa kelengkapan data, kesinambungan data diperoleh terutama dan data primer yang diperoleh melalui wawancara mendalam. Tujuan editing adalah untuk mengevaluasi dari data untuk mengurangi kesalahankesalahan yang terdapat didalamnya dan sebagai usaha kearah klarifikasi dan tabulasi dan data tersebut.

Coding yang digunakan bersifat individual coding dengan cara mengelompokkan data menurut variabel yang telah ditentukan pada landasan teori segera setelah data diperoleh. Unit coding akan dibuat berupa kalimat atau paragraf.

Membuat hasil penulisan yang didapatkan berupa kata, kalimat, atau paragraph yang mempunyai makna tertentu. Hal ini dilaku kan dengan tujuan untuk men sinkronkan pendapat responden satu dengan responen lainnya. Mengintegrasikan hasil wawancara yang sudah sistematis tersebut dengan teori-teori penelusuran kepustakaan yang ada. Dari karakteristik data dan kategori yang didapatkan peneliti membuat uraian secukupnya untuk mendapatkan gambaran yang utuh tentang karakteristik yang diteliti.
Supaya data yang banyak tersebut mudah dipahami baik oleh peneliti sendiri maupun orang lain, maka setelah direduksi data tersebut perlu disajikan. Penyajian data dalam bentuk uraian hasil observasi dan wawancara. Secara lengkap hasil penelitian ini disajikan pada bab IV dan pada bagian lampiran (berupa ringkasan hasil wawancara).

Penarikan Kesimpulan atau Verifikasi, setelah data disajikan secara rinci, maka langkah selanjutnya membahas terhadap data yang telah disajikan tersebut. Dalam membahas ini peneliti dapat memberikan tafsiran, argument, menemukan makna dan mencari hubungan antara saru komponen dengan komponen yang lain serta dikaitkan dengan beberapa teori pendukung. Menurut Nasution (1998), analisis data kualitatif dilakukan sejak penelitian dilakukan. Oleb karenanya data yang diperoleh dari lapangan segera disalin dalam bentuk tulisan dan kemudian dianalisis.

\section{HASIL PENELITIAN}

Penelitian ini dilaksanakan di RS Muhammadiyah Petanahan selama bulan Februari 2013. Penelitian bertujuan untuk mengetahuai rencana strategis bisnis RS PKU Muhammadiyah Petanahan untuk dapat bersaing dengan rumah sakit sejenis lainnya. Subyek dalam penelitian ini adalah komponen yang berkaitan langsung dengan perencanaan rencana strategis bisnis Rumah Sakit Muhammadiyah Petanahan yang terdiri dari kepala bagian, perawat dan bidan serta Kepala Dinas Kabupaten Gombong. Pengambilan data dilakukan dengan wawancara berdasarkan pedoman wawancara yang telah disiapkan oleh peneliti

Berdasarkan penelitian yang telah dilakukan didapatkan hasil-hasil sebagai berikut:

\section{Gambaran umum RS Muhammadiyah Petanahan}

Berdasarkan pengamatan yang dilakukan peneliti selama bekerja di RS PKU Muhammadiyah Petanahan dapat diketahui faktor analisis SWOT sebagai berikut:

\section{Kekuatan (Strength)}

Merupakansatu-satunya Rumah Sakit yang ada di jalur Selatan Selatan, yang merupakan jalur alternatif lintas selatan pulau Jawa yang menghubungkan Jawa Barat, Jawa Tengah, DIY dan Yogyakarta. Dukungan jaringan yang organisasi yang kuat dan solid.

\section{Kelemahan (Weakness)}


Banyaknya RS sejenis yang ada di sekitar Petanahan Kebumen, Kurangnya informasi tentang rumah sakit, Kurang memadainya SDM sampai belum bisa melengkapi struktur organisasi

\section{Kesempatan (Oportunity)}

Pangsa pasar yang luas, Tarif RS yang bisa bersaing dengan RS lain, RS PKU Muhammadiyah Petanahan telah memiliki tempat tersendiri di hati masyarakat sehingga keberadaan ini bisa menjadi kesempatan untuk menarik konsumen yang loyal.

\section{Ancaman (Threath)}

Keterbatasan fasilitas dan layanan di RS PKU Muhammadiyah Petanahan mengharuskan kita untuk merujuk pasien ke Rumah Sakit dengan layanan yang lebih lengkap, kondisi tersebut menjadi ancaman karena lambat laun mengurangi kepercayaan masyarakat terhadap rumah sakit.

Permasalahan utama yang dihadapi RS Muhammadiyah Petanahan adalah kurangnya rumusan perencanaan yang dapat mendukung pengembangan perencanaan strategis dalam bidang bisnis dan pelayanan kesehatan. Memperhatikan kelemahan RS Muhammadiyah Petanahan) perlu dilakukan perencanaan untuk dapat memenuhi kebutuhan tenaga kesehatan dan kelengkapan struktur rumah sakit. Salah satu perencanaan strategis bisnis adalah konsep perencanaan berdasarkan analisis SWOT rumah sakit.

\section{Gambaran umum subyek penelitian}

Subyek penelitian atau responden dalam penelitian ini adalah orang-orang yang dipandang terlibat dalam perencanaan strategi bisnis rumah sakit atau dapat memberikan masukan bagi perencanaan strategi bisnis rumah sakit. Responden dalam penelitian ini adalah Kepala Dinas Kesehatan Kabupaten Gombong, Kepala Bagian RS Muhammadiyah Petanahan yang meliputi Kepala Bagian Keperawatan, Kapala Bagian Farmasi, Kepala Bagian Laboratorium, Kepala Bagian IGD, Kepala Bagian Irja, Kapala Bagian Irna, Kepala Bagian Personalia, Kepala Bagian Pemasaran, Perawat dan Bidan masing-masing 1 orang. Dengan demikian jumlah subyek penelitian ini berjumlah 11 orang.

\section{Hasil wawancara dengan subyek penelitian}

Setelah membaca berulang-ulang hasil transkrip wawancara dan catatan lapangan dari masing-masing responden, peneliti mengidentifikasi kutipan kata dan pernyataan yang bermakna yang berhubungan dengan fenomena penelitian, kemudian membuat kategori dan tema utama.

Berdasarkan tujuan penelitian didapatkan tema utama sebagai berikut: Informasi Rencana Srategi Bisnis Rumah Sakit

Informasi merupakan bagian penting untuk membentuk opini tentang suatu hal termasuk rencana strategi bisnis rumah sakit. Adanya informasi rencana strategi bisnis rumah sakit memberikan harapan sekaligus menumbuhkan inspirasi bentuk strategi yang akan diterapkan. Meskipun telah ada informasi tentang rencana strategi bisnis rumah sakit, namun belum semua pegawai atau karyawan rumah sakit mendengar atau mengetahui secara detail rencana strategi bisnis rumah sakit. Jawaban responden terhadap pertanyaan tentang pernah tidaknya mendengar informasi tentang rencana strategi bisnis rumah sakit bervariasi seperti ditunjukkan pada kutipan hasil wawancara sebagai berikut:

Detailnya belum tahu. Hanya pernah mendengar informasi bahwa RS Muhammadiyah Petanahan akan dikembangkan. Yaa itu tadi, detailnya bagaimana belum tahu juga. (R1)

Kayaknya pernah denger informasi itu. Mungkin adanya pembangunan dan penambahan sarana dan prasarana di rumah sakit ini mengindikasikan pelaksanaan rencana stratgis bisnis yang dimaksud (R2)

Pernah juga diajak omong-omong soal rencana strategis bisnis bagi pengembangan rumah sakit. Kita bicara panjang lebar tentang rencana pengembangan rumah sakit termasuk rencana strategi bisnis rumah sakit (R3)

Ya tau doong......kita inikah orientasinya ke depan (R5)

Ya. Saya kan termasuk yang dipercaya untuk mengembangkan strategi bisnis rumah sakit ini. Jadi harus tahu rencana strategi bisnis rumah sakit ini. (R8)

Hasil wawancara terhadap responden didapatkan keterangan bahwa informasi tentang rencana strategis bisnis rumah sakit tidak tersebar secara merata namun sudah diketahui oleh semua karyawan rumah sakit. Adanya informasi yang tidak lengkap menumbuhkan sikap tidak puas dikalangan staf rumah sakit sehingga banyak yang menginginkan adanya seminar khusus untuk membahas rencana strategi bisnis rumah sakit. Keinginan sebagian 
besar responden tersebut tercermin dalam hasil wawancara tentang perlunya diadakan seminar rencana strategi bisnis rumah sakit sebagai berikut:

Ya. Untuk membangun opini sekaligus memberikan gambaran kepada karyawan RS Muhammadiyah Petanahan tentang rencana strategis bisnis RS Muhammadiyah Petanahan (R1, R9)

Yo jelas. Wong kita ini kan dalam satu institusi, harus adalah saling keterbukaan informasi, pa lagi ni menyangkut kepentingan bersama (R2)

Saya kira itu perlu dilakukan. Terutama seminar untuk kalangan sendiri yaitu seluruh staf rumah sakit sebagai upaya sosialisasi rencana strategi bisnis rumah sakit sekaligus untuk menyaring adanya masukan-masukan bagi pengembangan rumah sakit.(R3, R6, R11)

Perlu lah. Itukan untuk membangun wacana supaya semua orang tahu bahwa rumah sakit ini mau dibangun dan dikembangkan. Gitu..!!!! (R5)

Bila memungkinkan untuk dilakukan ya dilakukan. Bila tidak, yang penting ada sosialisasi bagi seluruh karyawan rumah sakit bahwa rumah sakit ini akan dikembangkan sehingga mereka bisa menyesuaikan diri. (R8)

Adanya keinginan untuk dilakukan seminar khusus tentang rencana strategi bisnis rumah sakit menunjukkan bahwa banyak responden yang berharap agar rumah sakit Muhammadiyah Petanahan dapat dikembangkan dan menjadi yang terbaik dalam memberikan pelayanan kesehatan kepada masyarakat. Hasil wawancara berikut menunjukkan hal tersebut.

Saya selalu berharap yang yang terbaik bagi rumah sakit ini. Bagaiamanapun juga saya adalah bagian dari rumah sakit ini. Kalo rumah sakit baik, harapannya, saya juga akan menjadi baik (R1, R7, R11)

Ya dong. Kita kan berharap ada peningkatan di rumah sakit, kualtias maupun in come karyawannya, termasuk saya,...he....he....he... (R2, R4, R5)

Saya kira setiap bagian dari rumah sakit ini.baik staf, tenaga medis dan non medis tentunya mengharapkan rumah sakit ini berkualitas dan berdaya saing tinggi karena pada hakikatnya kemajuan rumah sakit ini juga meningkatkan kesejahteraan karyawannya. Harapannya demikian. (R3, R6, R8)
Iya ho oh. Kita pingin rumah sakit ini berkualtias dan memiliki daya saing tinggi (R9, R10)

Berdasarkan hasil wawancara dengan responden dapat disimpulkan bahwa setiap staf di rumah sakit berharap agar rencana strategi bisnis rumah sakit dapat diinformasikan secara menyeluruh kepada semua staf rumah sakit melalui seminar khusus karena rumah sakit yang berkualitas menjadi harapan dan keinginan semua komponen rumah sakit.

Analisis SWOT Sebagai Landasan Rencana Srategi Bisnis Rumah Sakit

Harapan untuk menjadikan rumah sakit Muhammadiyah Petanahan sebagai rumah sakit yang berkualitas dan berdaya saing tinggi harus diimbangi dengan perencanaan yang matang. Pengukuran kemampuan diri menjadi bagian penting bagi rencana strategi bisnis rumah sakit. Analisis SWOT sebagai komponen penting dalam perencanaan strategi bisnis rumah sakit memiliki peran yang harus diperhitung secara nyata. Hasil wawancara berikut ini menunjukkan bahwa bagi responden, analisis Swot rumah sakit Muhammdiyah Petanahan sudah dapat dijadikan landasan bagi rencana strategi bisnis rumah sakit.

Analisis SWOT ya....emm...menurut saya masih diperlukan perencanaan yang lebih matang tentang rencana strategi bisnis maupun sarana prasaranya. Profil RS ini memberikan prospek yang menjanjikan bila dikaji dengan analisis SWOT meskipun tidak dipungkiri ada beberapa kelemahan, namun masih bisa diatasi (R1)

Menurut saya, itu dapat dilakukan, tergantung siapa yang melakukannya. Jangankan hanya perencanaan strategi bisnis. Membangun jaringan bisnis yang lebih besar pun saya kira bis dilakukan. (R3)

Saya pikir dapat juga SWOT sebagai landasan perencanaan strategis bisnis ini. (R5)

SWOT itu yang kami jadikan landasan utama rencana strategi bisnis rumah sakit. (R7)

Analisis SWOT itu justru hal penting untuk bahan pertimbangan perencanaan pengembangan. (R11)

Dijadikannya analisis SWOT sebagai landasan rencana strategi bisnis rumah sakit didasari oleh keyakinan bahwa dipandang dari sisi analisis SWOT, rumah sakit Muhammadiyah Petanahan memeliki prostpek yang 
menjanjikan untuk dikembangkan lebih maju. Hasil wawancara berikut memberikan gambaran hal tersebut.

Secara pribadi saya melihat rumah sakit ini memiliki banyak potensi untuk dikembangkan mulai dari lokasi yang strategis, kinerja perawat serta komponen-komponen lain yang memungkinkan untuk dikembangkan. Dari situ dah terlihat bahwa rumah sakit ini memiliki prospek ke depan yang cukup menjanjikan. (R3)

SWOT ya. Saya pikir ya. Meski rumah sakit ini punya banyak kekurangan, namun tetap memiliki prospek cerah untuk mewujudkan rencana strategi bsinis rumah sakit. (R5)

Prospek itu selalu ada, dilihat dari sudut pandang manapun. Masalah kekurangan, ya itu wajarlah, wong baru berkembang (R6)

Sangat menjanjikan. Makanya kita membangun gedung baru sebagai langkah awal pengembangan strategi bisnis rumah sakit. (R7)

Itu juga sudah kami perhitungkan. Kita mencoba menggunakan kelebihan kita untuk menutupi kelemahan kita sehingga prospek yang diharapkan menjadi lebih baik (R8)

Saya lihat, RS Muhammadiyah Petanahan memiliki prospek yang baik untuk dikembangkan (R11)

Berdasarkan hasil wawancara tersebut dapat disimpulkan bahwa analisis SWOT dapat dijadikan landasan untuk merencanakan strategi bisnis rumah sakit dengan memperhatikan bahwa dilihat dari sisi analisis SWOT, rumah sakit Muhammadiyah Petanahan memiliki prospek yang menjanjikan untuk dikembangkan meskipun memiliki banyak kekurangan.

Rencana Srategi Bisnis Rumah Sakit Yang Akan Diterapkan Untuk Mengatasi Kelemahan Rumah Sakit

Rencana strategi bisnis rumah sakit tentunya memiliki banyak persyaratan yang dibutuhkan untuk dapat mewujudkannya. Komponen-komponan rencana strategi bisnis rumah sakit yang dibutuhkan antara lain executive summery, gambaran umum rumah sakit, rencana pemasaran, rencana Produksi atau jasa layanan yang akan disediakan, rencana keuangan, rencana sumber daya manusia, analisis persaingan rumah sakit, risiko utama yang dihadapi dari perencanaan strategi bisnis rumah sakit dan penelitian dan pengembangan manajemen. Perhitungan secara matang terhadap perencanaan tersebut dapat menjadi salah satu faktor keberhasilan rencana strategi bisnis rumah sakit. Salah satu gambaran perencanaan komponen rencana strategi rumah sakit seperti di perlihatkan pada hasil wawancara berikut:

(R1) :

Saya kira cukup mendukung hal tersebut. Profil rumah sakit dan fasilitas yang dimiliki cukup menjanjikan meskipun masih banyak yang perlu dilengkapi, namun secara umum sudah dapat memberikan harapan rencana strategis bisnis RS.

Menurut saya secara umum bisa, namun perlu pembenahan yang cukup sehingga benar-benar siap untuk menjalankan bisnis rumah sakit.

Selama ini baru dalam tahap promosi pelayanan kesehatan disamping rencana penambahan fasilitas sarana dan prasarana baik peralatan yang lebih modern, penambahan gedung baru maupun tenaga trampil yang lebih profesional.

Selama ini kami telah membuka layanan dokter 24 jam dan pelayanan gawat darurat. Harapan ke depannya dapat dibuka layanan poli 24 jam sehingga masyarakat dapat lebih memanfaatkan jasa layanan rumah sakit secara optimal kapanpun.

Emmm....terus terang kalo masalah keuangan saya belum memahami. Sepenuhnya hal itu hanya diketahui oleh pihak pengelola rumah sakit dan bidang keuangan rumah sakit.

Eee........sumber daya manusia ya.....kaitannya dengan perencanaan strategi bisnis rumah sakit,....sepengetahuan saya belum terlalu dikedepankan. Kalo pemberian kesempatan belajar atau melanjutkan sekolah memang ada, namun secara khusus yang terkait dengan rencana strategis bisnis rumah sakit, kok saya malah belum dengar ya....

Persaingan rumah sakit ya,....selama ini saya kok jarang ya, membandingkan rumah sakit ini dengan rumah sakit lainnya. Selama ini saya lebih terfokus pada pelayanan keperawatan di rumah sakit. Mungkin nanti kalo ada waktu saya bisa melakukan studi banding ke rumah sakit lainnya.

Yaa....paling-paling kembali seperti semula. Kayak gini lagi

Setahu saya, penelitian yang terkait langsung dengan perencanaan strategis bisnis rumah sakit belum ada. Tapi kalo dijadikan tempat penelitian rumah sakit, sering.....banyak lah..... 
Saya kira Executive summery itu bagian dari perencanaan strategi bisnis yang akan dijalankan. Dari yang saya amati, emang ada kesesuaian Executive summery dengan perencanaan strategi bisnis yang akan dijalankan

Ya. Gambaran umum rumah sakit ini mencerminkan harapan untuk dikembangkan lebih besar lagi. Pembangunan gedung baru yang saat ini sedang dilakukan memperlihatkan hal tersebut.

Rencana pemasarannya, dari yang saya pahami, emang kita akan menggunakan semua fasilitas dan potensi yang dimiliki, termasuk media cetak dan elektronik

Yang jelas akan ada penambahan layanan kesehatan sebagai konsekuensi rencana pengembangan bisnis.

Saya gak paham kalo itu. Pembahasan kemarin belum sampai gitu. Masih dalam tahap perencanaan produk jasa dan pemasaran ditambah komponen-komponen lain yang mendukung. Harapannya, adanya peningkatan strategi bisnis, juga diimbangi dengan peningkatan in come karyawan

Kemungkinan kita akan melakukan penambahan karyawan sesuai dengan kebutuhan. Tentunya yang mendukung perencanaan bisnis.

Saya kira rumah sakit lain juga melakukan hal yang sama dengan yang sekarang kita lakukan. Makanya kita optimis aja bahwa kita bisa lebih baik dari mereka semua dengan segala keterbatasan yang dimiliki

Kami tidak memikirkan hal itu.

Penelitian langsung yang terkait dengan rencana strategis bisnis, emang belum pernah. Apa yang sekarang dilakukan hanyalah realisasi hasil observasi selama beberapa tahun yang lalu

(R5)

Executive summery itukan wujud nyata dari kinerja tenaga medis di sini. Saya kira sudah menunjukkan performance yang baik untuk dapat dikembangkan lebih lanjut.

Menurut saya ya begitu itu, rumah sakit inikan sudah dikenal oleh masyarakat, jadinya sudah cukup untuk menjadi landasan rencana strategi bisnis rumah sakit.
Selama ini, kalo disini, promosi dari mulut ke mulut sudah menjadi media pemasaran paling efektif, efisien dan murah

Rencana produksi kami, ya harapannya nanti di sini ada dokter spesialisnya. Dibuat ruangan-ruangan untuk masing-masing spesialis

Waduh kalo yang itu belum ada omong-omong yang pasti. Hanya ja emang kemungkinan akan ada fee tambahan seiring dengan bertambahkan beban kerja

Penambahan dokter spesialis di sini itu yang penting, jadinya orang tu melihat,.........yang menangani dokter spesialis semua,.....gitu

Saya belum pernah membandingkan rumah sakit ini dengan rumah sakit lain. Hanya saja berdasarkan omongan dari pasien yang dapat kemari, disini tu lebih baik dari rumah sakit lain

Kalo rencana strategis bisnis ini gagal atau gak jalan ya kami nggak da pasien. Nganggur dong.

Pernah sih. Tentang kinerja perawat atau tentang kepuasan pasien terhadap kualitas pelayanan kesehatan. Hasilnya pasien banyak yang merasa puas. Dan kualitasnya termasuk bagus.

\section{(R6)}

Saya kira apa yang kami lakukan sudah menunjukkan executive summery yang cukup memberikan gambaran untuk mendukung rencana strategi bisnis.

Ya.

Memberikan pelayanan yang optimal dan menumbuhkan kesan yang baik pada pasien, saya kira merupakan bentuk pemasaran yang lebih efektif.

Rencana produksi kami sebenarnya tidak lepas dari kinerja kami sebagai perawat. Menjadikan pasien dan keluarganya sebagai bagian dari kami, saya pikir merupakan hal yang penting.

Kalo itu terus terang saya tidak tahu

Menurut saya, profesionalkan yang telah ada atau tambah lagi yang lebih profesional. SDM yang sekarang bukannya kurang profesional, namun memang ada beberapa kelemahan, diantaranya adanya perbedaan pelayanan pada pasien tiap bangsal. 
Analisis persaingan rumah sakit ya. Bagaimanapun keadaan rumah sakit ini, saya percaya bahwa rumah sakit ini bisa lebih baik lagi.

Yaa....jalan ditempat

Pernah juga tentang kepuasan pasien terhadap kinerja dan mutu pelayanan perawat.

Selama ini kami menjadikan kepuasan pasien terhadap pelayanan rumah sakit sebagai modal untuk mengembangkan rencana strategi bisnis rumah sakit

Lokasi dan respon masyarakat terhadap rumah sakit ini sudah memberikan jaminan keberlangsungan rendana strategi bisnis rumah sakit.

Banyak yang kita gali dari informasi yang kami miliki. Salah satunya dengan memiliki orang yang tepat atau memiliki kemampuan dalam memasarkan suatu produk

Rencana produksi yang riil adalah dengan menyediakan layanan spesialis, menjadikan rumah sakit ini sebagai rumah peristirahatan yang nyaman bagi pasien strata apapun. Kita lebih mengedepankan bukti nyata daripada sekedar slogan

Kita nanti akan melakukan pembagian secara proporsional dan profesional sesuai dengan beban kerja dan pendapatan rumah sakit

Kita pilihkan tenaga yang trampil dan profesional. Kita berikan kesempatan kepada perawat, bidan atau tenaga kerja di rumah sakit ini untuk mengembangkan kemampuannya sendiri, baik melalui pendidikan formal seperti melanjutkan studi atau pelatihan-pelatihan lain yang mendukung.

Dari informasi yang kita miliki, kita memiliki kelebihan dibandingan rumah sakit lain dair segi keramahan pelayanan kesehatan disamping harga yang relatif lebih murah tanpa mengesampingkan profesionalisme tenaga kesehatan.

Ya. Dan itu sudah kami perhitungkan secara matang

Khusus yang ini belum pernah.
Bagi saya executive summery RS Muhammadiyah Petanahan cukup merepresentasikan perencanaan strategi bisnis.

Menurut saya secara umum bisa, namun perlu pembenahan yang cukup sehingga benar-benar siap untuk menjalankan bisnis rumah sakit.

Yang saya tahu, selama ini baru dalam tahap promosi pelayanan kesehatan disamping penambahan gedung baru yang sedang dibangun

Nah itu dia.katanya masih digodog biar matang, katanya berkaitan juga dengan fasilitas yang akan disediakan.

Saya kok belum dapat informasi itu ya

Itulah dia yang penting untuk diperhatikan. Katanya hal tersebut sudah dipersiapkan dengan berbagai cara baik dengan meningkatkan kemampuan karyawan rumah sakit maupun merekrut karyawan baru sesuai kebutuhan

Persaingan rumah sakit ya,....selama ini saya kok jarang ya, membandingkan rumah sakit satu dengan rumah sakit lainnya.

\section{Saya kira mereka sudah mempersiapkannya}

Setahu saya belum ada yang seperti ini di rumah sakit manapun di wilayah kerja saya.

Berdasarkan hasil wawancara dapat diketahui bahwa komponen-komponen rencana strategi bisnis rumah sakit secara umum sudah dipersiapkan secara matang namun belum disosialiasikan kepada karyawan di rumah sakit Muhammadiyah Petanahan. Kurangnya sosialisasi tersebut dapat diketahui bahwa hanya beberapa kepala bagian saja yang benar-benar mengetahui dan memahami rencana strategi bisnis rumah namun belum diutarakan secara rinci. Ada beberapa hal yang memang tidak dipublikasikan kepada umum seperti masalah manajemen keuangan yang kewenangan informasi diserahkan kepada bagian keuangan dan direktur rumah sakit.

\section{Pembahasan}

Perencanaan strategik merupakan perangkat manajemen penting yang dapat membantu organisasi dalam melakukan tugasnya dengan lebih baik. Memfasilitasi pengembangan strategi dan implementasi, serta organisasi menjadi lebih sensitif terhadap kebutuhan pelanggan dan pasar (Bonn \& Christodoulou, 1996; Obeng \& Ugboro 2008). Perencanaan strategik (strategic planning) vital bagi 
organisasi dalam mempertahankan kelangsungan hidupnya (Robbins \& Coulter, 2007; Jauch \& Glueck, 2004; Wheleen \& Hunger, 2004).

Faktor sukses kunci penerapan perencanaan strategik adalah proses formulasi strategi yang sistematis, pelaksanaan atau implementasi strategi yang efektif, dan pengendalian serta tindak lanjut dari implementasi (Brenes, et al. 2008). Aliran informasi dan komunikasi adalah kritikal untuk kese-luruhan integrasi dan keefektivan perencanaan stra-tegik (Ocasio \& Joseph, 2008). Menurut pandangan berbasis sumber daya, the resource based view of the firm (RBV), sumber daya yang dimiliki rumah sakit dapat menjadi sumber yang memungkinkan untuk memperkirakan dan mengimplementasikan strategi yang dapat meningkatkan efisiensi dan efektivitas rumah sakit (Barney, 1991). Sumber daya dan kapabilitas rumah sakit merupakan prinsip dasar strategi dan faktor penentu profitabilitas rumah sakit (Grant, 1997; Collis \& Montgomery,1998). Semakin besar laju perubahan lingkungan eksternal, pencarian dasar strategi jangka panjang dari sumber daya dan kappa-bilitas internal lebih diperlukan dari pada fokus pasar eksternal.

Dalam menyusun perencanaan strategi bisnis rumah sakit, langkah awal yang penting untuk dilakukan adalah membentuk persamaan persepsi diantara komponen rumah sakit, terutama staf rumah sakit. Pemberian informasi kepada staf rumah sakit merupakan langkah yang penting untuk menyamakan persepsi. Penelitian ini menunjukkan bahwa informasi tentang rencana strategi rumah sakit masih belum merata. Masih didapatkan responden yang belum memahami rencana strategi rumah sakit.

Detailnya belum tahu. Hanya pernah mendengar informasi bahwa RS Muhammadiyah Petanahan akan dikembangkan. Yaa itu tadi, detailnya bagaimana belum tahu juga. (R1)

Kayaknya pernah denger informasi itu. Mungkin adanya pembangunan dan penambahan sarana dan prasarana di rumah sakit ini mengindikasikan pelaksanaan rencana stratgis bisnis yang dimaksud (R2)

Hasil wawancara terhadap responden didapatkan keterangan bahwa informasi tentang rencana strategis bisnis rumah sakit tidak tersebar secara merata namun sudah diketahui oleh semua karyawan rumah sakit. Respondrn yang mengetahui rencana strategi bisnis rumah sakit akan berusaha untuk menyesuaikan aktifitas dalam bekerja dengan tujuan rencana strategi bisnis rumah sakit.

Saya harap demikian.meskipun mungkin apa yang saya kerjakan belum mencerminkan perencanaan tersebut secara keseluruhan namun saya berharap merupakan bagian untuk mewujudkan rencana tersebut
Jawaban responden terhadap pertanyaan tentang kesesuaian aktifitas bekerja dengan rencana strategi bisnis rumah sakit mencerminkan hal tersebut

Adanya informasi yang tidak lengkap menumbuhkan sikap tidak puas dikalangan staf rumah sakit sehingga banyak yang menginginkan adanya seminar khusus untuk membahas rencana strategi bisnis rumah sakit. Keinginan sebagian besar responden tersebut tercermin dalam hasil wawancara tentang perlunya diadakan seminar rencana strategi bisnis rumah sakit sebagai berikut:

Ya. Untuk membangun opini sekaligus memberikan gambaran kepada karyawan RS Muhammadiyah Petanahan tentang rencana strategis bisnis RS Muhammadiyah Petanahan (R1, R9)

Saya kira itu perlu dilakukan. Terutama seminar untuk kalangan sendiri yaitu seluruh staf rumah sakit sebagai upaya sosialisasi rencana strategi bisnis rumah sakit sekaligus untuk menyaring adanya masukan-masukan bagi pengembangan rumah sakit.(R3, R6, R11)

Adanya keinginan untuk dilakukan seminar khusus tentang rencana strategi bisnis rumah sakit menunjukkan bahwa banyak responden yang berharap agar rumah sakit Muhammadiyah Petanahan dapat dikembangkan dan menjadi yang terbaik dalam memberikan pelayanan kesehatan kepada masyarakat. Hasil wawancara berikut menunjukkan hal tersebut.

Saya kira setiap bagian dari rumah sakit ini.baik staf, tenaga medis dan non medis tentunya mengharapkan rumah sakit ini berkualitas dan berdaya saing tinggi karena pada hakikatnya kemajuan rumah sakit ini juga meningkatkan kesejahteraan karyawannya. Harapannya demikian. (R3, R6, R8)

Berdasarkan hasil wawancara dengan responden dapat disimpulkan bahwa setiap staf di rumah sakit berharap agar rencana strategi bisnis rumah sakit dapat diinformasikan secara umum kepada semua staf rumah sakit melalui seminar khusus karena rumah sakit yang berkualitas menjadi harapan dan keinginan semua komponen rumah sakit.

Rencana Srategi Bisnis Rumah Sakit Yang Akan Diterapkan Untuk Mengatasi Kelemahan Rumah Sakit

Suatu rumah sakit dapat mengembangkan strategi bersaing dengan cara mencari kesesuaian antara kekuatankekuatan internal rumah sakit dan kekuatan kekuatan eksternal tersebut. Pengembangan strategi bersaing ini bertujuan agar rumah sakit dapat melihat secara objektif kondisi-kondisi internal dan eksternal sehingga dapat mengantisipasi perubahan lingkungan eksternal, yang sangat penting untuk memperoleh keunggulan bersaing dan 
memiliki produk yang sesuai dengan keinginan konsumen dengan dukungan optimal dari sumber daya yang ada (Rangkuti, 2005). Pentingnya strategi adalah merupakan alat untuk mencapai tujuan rumah sakit jangka panjang dan terus menerus dilakukan berdasarkan sudut pandang tentang apa yang dihadapi oleh para pesaing dimasa depan untuk mencapai keunggulan bersaing. Sedangkan menurut Jauch dan Glueck (1993), strategi adalah rencana yang disatukan, menyeluruh, dan terpadu yang mengaitkan keunggulan strategi rumah sakit dengan tantangan lingkungan yang dirancang untuk memastikan bahwa tujuan utama rumah sakit dapat dicapai melalui pelaksanaan yang tepat oleh rumah sakit.

Salah satu metode yang dapat digunakan untuk mengembangkan rencana strategi bisnis rumah sakit adalah metode analisis SWOT (strengths, weaknesses, opportunities, dan threats). Analisis SWOT adalah metode perencanaan strategis yang digunakan untuk mengevaluasi kekuatan (strengths), kelemahan (weaknesses), peluang (opportunities), dan ancaman (threats) dalam suatu proyek atau suatu spekulasi bisnis. Keempat faktor itulah yang membentuk akronim SWOT. Proses ini melibatkan penentuan tujuan yang spesifik dari spekulasi bisnis atau proyek dan mengidentifikasi faktor internal dan eksternal yang mendukung dan yang tidak dalam mencapai tujuan tersebut. Analisis SWOT dapat diterapkan dengan cara menganalisis dan memilah berbagai hal yang mempengaruhi keempat faktornya.

Kelemahan RS Muhammadiyan seperti kurangnya informasi tentang rumah sakit dan kurang memadainya SDM sampai belum bisa melengkapi struktur organisasi dapat diatasi dengan memanfaatkan keunggulan dan kesempatan yang dimilikinya seperti dukungan jaringan yang organisasi yang kuat dan solid dan respon masyarakat yang baik sehingga memiliki nilai tersendiri di hati masyarakat. Seperti yang dikemukakan oleh responden (R5) ketika menjawab pertanyaan tentang produk jasa yang akan direncanakan

Memberikan pelayanan yang optimal dan menumbuhkan kesan yang baik pada pasien, saya kira merupakan bentuk pemasaran yang lebih efektif.

Pembenahan manjerial yang baik dengan memanfaatkan soliditas organisasi yang baik serta semua fasilitas yang dimiliki dapat menumbuhkan kekuatan tersendiri untuk menciptakan nilai plus dan dapat diterima oleh masyarakat. Penambahan gedung baru yang sedang dibangun merupakan bentuk realisasi dari keinginan untuk mengembangkan rencana strategi bisnis rumah sakit. Pembangunan gedung baru diharapkan dapat diimbangi dengan penambahan fasilitas kesehatan yang memadai sehingga benar-benar dapat mewujudkan rencana strategi bisnis yang diinginkan.

Pembangunan gedung baru selain menunjukkan keseriusan untuk mengembangkan rumah sakit juga memberikan gambaran kesiapan dalam mewujudkan rencana strategi bisnis rumah sakit (Executive summary). Alasan utama pembangunan gedung baru adalah menumbuhkan kepercanaan kepada publik terutama investor bahwa RS Muhammdiyah Petanahan memiliki prospek yang cerah dan menjanjikan. Sebelum menyusun executive summary, satu hal yang perlu diingat ialah tujuan menyusun executive summary bukan untuk membuat seorang investor memberikan Anda cek berisi uang. Akan tetapi ada tujuan yang lebih utama lagi, yaitu membuat calon investor itu membaca business plan perusahaan hingga tuntas dan menjadwalkan sebuah pertemuan atau rapat dengan perusahaan.

Rencana strategi bisnis rumah sakit harus didukung adanya pemasaran yang dapat mereprentasikan prospek rumah sakit ke depannya. Untuk itu dibutuhkan lebih banyak konsep pemasaran yang harus dikaji secara matang. Pemasaran meliputi: perencanaan dan pelaksanaan penetapan harga, promosi, dan distribusi produk. Pemasaran juga harus dapat mengetahui secara tepat setiap perubahan yang terjadi dengan prilaku konsumen. Dari hasil pemantauan pemasaran ini dibawa ke rapat manajemen puncak untuk dibahas dan dirumuskan dalam proses manajemen strategi. Analisis pasar akan meliputi: analisis pasar, analisis kecenderungan pasar, analisis peluang pasar, dan analisis segmentasi pasar. Prinsip utama dalam pemasaran adalah bagaimana mengupayakan agar produk yang dihasilkan dapat diterima konsumen. Pemasaran memainkan peranan penting bagi kesuksesan usaha. Kunci utamanya, kita harus memahami kebutuhan atau keinginan pasar (pelanggan)

Hasil wawancara menunjukkan bahwa dalam manajemen pemasaran akan memanfaatkan semua fasilitas yang ada seperti yang dikemukakan oleh responden (R3)

Rencana pemasarannya, dari yang saya pahami, emang kita akan menggunakan semua fasilitas dan potensi yang dimiliki, termasuk media cetak dan elektronik

Hasil wawancara tersebut memberikan indikasi bahwa penggunaan semua media informasi merupakan pilihan yang terbaik dalam mempromosikan rumah sakit. Media cibernet merupakan alternatif utama dalam penyampaian promosi rumah sakit. Hal tersebut karena jangkauan cybernet lebih luas dengan biaya relatif lebih murah.

Selain pemasaran faktor lain yang turut membantu pelaksanaan rencana strategi bisnis rumah sakit adalah produksi jasa yang unggul. Produksi jasa yang unggul 
memberikan kepuasan tersendiri kepada pasien kehingga pasien akan menggunakan jasa yang sama untuk keluhan yang sama ataupun berbeda. Bahkan pasien dapat membagi informasi kepuasan yang diperolehnya kepada orang lain sehingga memudahkan rumah sakit dalam menyebarluaskan informasi tentang jasa layanan kesehayan yang diberikan.

Hasil wawancara dengan responden memberikan gambaran sebagai berikut:

\section{R1:}

Selama ini kami telah membuka layanan dokter 24 jam dan pelayanan gawat darurat. Harapan ke depannya dapat dibuka layanan poli 24 jam sehingga masyarakat dapat lebih memanfaatkan jasa layanan rumah sakit secara optimal kapanpun.

\section{R5:}

Rencana produksi kami, ya harapannya nanti di sini ada dokter spesialisnya. Dibuat ruangan-ruangan untuk masing-masing spesialis

R7:

Rencana produksi yang riil adalah dengan menyediakan layanan spesialis, menjadikan rumah sakit ini sebagai rumah peristirahatan yang nyaman bagi pasien strata apapun. Kita lebih mengedepankan bukti nyata daripada sekedar slogan

Hasil wawancara dengan responden tersebut memberikan kesimpulan bahwa rencana produksi jasa yang akan diberikan lebih berorientasi pada kepuasan pasien. Menjadikan kepuasan pasien sebagai tujuan perumusan jasa produksi dapat memberikan nilai plus di hati pasien. Apalagi penanganan dilakukan oleh tenaga profesional atau spesialis, semakin menjadikam pasien merasa yakin dengan kualitas pelayanan jasa kesehatan yang disediakan.

Hasil wawancara dengan responden juga didapatkan informasi bahwa banyak responden yang tidak mengetahui rencana keuangan secara detail. secara garis besar diketahui bahwa perubahan rencana strategi bisnis rumah sakit juga diimbangi dengan perubahan manajemen keuangan. Bagaimana bentuk perubahannya belum diinformasikan secara jelas. Hasil wawancara dengan semua responden mengindikasikan hal tersebut.

\section{R1:}

Emmm....terus terang kalo masalah keuangan saya belum memahami. Sepenuhnya hal itu hanya diketahui oleh pihak pengelola rumah sakit dan bidang keuangan rumah sakit.

R5:
Waduh kalo yang itu belum ada omong-omong yang pasti. Hanya ja emang kemungkinan akan ada fee tambahan seiring dengan bertambahkan beban kerja

R7:

Kita nanti akan melakukan pembagian secara proporsional dan profesional sesuai dengan beban kerja dan pendapatan rumah sakit

Dari hasil wawancara diatas dapat diketahui bahwa untuk masalah keuangan memang belum dibahas secara mendetail dan belum diinformasikan kepada semua karyawan rumah sakit. Namun ada indikasi bahwa akan ada penyesuaian pendapatan dengan beban kerja karyawan.

Untuk mengetahui sampai sejauhmana fungsi keuangan berjalan dengan efektif, maka analisis yang dilakukan berhubungan dengan analisis rasio, analisis pulang pokok (break event), analisis nilai sekarang, analisis nilai akan datang, analisis potensi, analisis penyimpangan dan keberhasilan, dan berbagai analisis lainnya. Dalam melakukan analisis di atas data yang diunakan biasanya diambil dari laporan keungan perusahaan.

Keuangan adalah "Nyawa dan Darah" dari usaha. Oleh karena itu kita harus benar-benar mempersiapkannya secara teliti, matang dan bijaksana, untuk keberhasilan suatu usaha, perhatikan hal-hal yang berkaitan dengan keuangan sebagai berikut : Anggaran harus realistis bukan fantastis !; Anggaran harus mencakup dana riil yang diperlukan untuk memulai usaha (start-up cost), dan dana untuk operasional sehari-hari (operating cost); Operating budget minimal harus dibuat untuk jangka waktu 3 hingga 6 bulan pertama; Bagian keuangan harus mencantumkan dana-dana luar yang dipakai, peralatan yang dimiliki dan daftar supplier atau pelanggan, neraca, analisa Break Even Point, proforma proyeksi laba rugi, dan proforma arus kas (cashflow) usaha; Proyeksi laba rugi dan cashflow harus dibuat paling tidak untuk 3 tahun ke depan dan Rencana yang dibuat harus dilengkapi penjelasan seluruh proyeksi yang dibuat, dan asumsi-asumsi yang dipakai.

Untuk dapat mewujudkan rencana strategis bisnis rumah sakit memang harus didukung dengan sumber daya manusia yang berkualitas. Tanpa adanya SDM yang memadai, rencana strategis bisnis rumah sakit hanya akan menjadi konsep yang tidak terealisasi. Hasil wawancara berikut menunjukkan pentingnya SDM bagi pengembangan bisnis rumah sakit.

R3:

Kemungkinan kita akan melakukan penambahan karyawan sesuai dengan kebutuhan. Tentunya yang mendukung perencanaan bisnis 
Penambahan dokter spesialis di sini itu yang penting, jadinya orang tu melihat,.........yang menangani dokter spesialis semua,......gitu

R6:

Menurut saya, profesionalkan yang telah ada atau tambah lagi yang lebih profesional. SDM yang sekarang bukannya kurang profesional, namun memang ada beberapa kelemahan, diantaranya adanya perbedaan pelayanan pada pasien tiap bangsal

Hasil wawancara tersebut memberikan indikasi bahwa untuk sumber daya manusia memang akan dipersiapkan dengan berbagai cara sehingga diperoleh kualtias SDM yang baik. Semua fungsi bisnis tidak akan berjalan dengan sendirinya meskipun telah dilengkapi dengan berbagai peralatan modern. Semua fungsi hanya akan bergerak jika dilengkapi dengan sumberdaya manusia. Kualitas pekerja biasanya sangat tergantung pada kualitas sumberdaya manusia. Semakin baik kualitas sumberdaya manusia, semakin baik pula kinerja dan produk yang dihasilkan dan akan semakin berkualitas pula proses manajemen strateginya. Analisis sumberdaya manusia dalam proses manajemen strategi meliputi: rekrutmen, pelatihan dan pengembangan.

Dalam proses manajemen strategi, penerimaan (rekrutmen) sumberdaya manusia harus melalui proses merit yaitu proses rekrutmen tenaga kerja berdasarkan pertimbangan rasional, obyektif. Tidak dibenarkan menggunakan sistem Spoil, yaitu proses rekrumen berdasarkan pertimbangan kenalan, hubungan baik, keluarga, suka dan tidak suka, serta belas kasihan.

Semua komponen rumah sakit penting untuk diperhitungkan sebagai modal pengembangan rumah sakit. Namun begitu kehadiran rumah sakit sejenis di wilayah kerja RS Muhammadiyah Petanahan juga menjadi pertimbangan dalam menyusun rencana strategi bisnis rumah sakit. Kehadiran rumah sakit di sekitar RS Muhammadiyah Petanahan dapat menjadi saingan dalam bisnis. Meskipun terdapat saingan yang dapat menghambat rencana strategis bisnis rumah sakit, RS Muhammadiyah Petanahan tetap memiliki prospek yang menjanjikan yaitu penerimaan masyarakat terhadap keberadaan RS Muhammadiyah Petanahan yang baik. Hasil wawancara berikut memberikan gambaran bagaimana RS Muhammadiyah Petanahan memandang rumah sakit lain yang sejenis sebagai pesaing.

R3:

Saya kira rumah sakit lain juga melakukan hal yang sama dengan yang sekarang kita lakukan. Makanya kita optimis aja bahwa kita bisa lebih baik dari mereka semua dengan segala keterbatasan yang dimiliki

R5:

Saya belum pernah membandingkan rumah sakit ini dengan rumah sakit lain. Hanya saja berdasarkan omongan dari pasien yang dapat kemari, disini tu lebih baik dari rumah sakit lain

\section{R6:}

Analisis persaingan rumah sakit ya. Bagaimanapun keadaan rumah sakit ini, saya percaya bahwa rumah sakit ini bisa lebih baik lagi.

R7:

Dari informasi yang kita miliki, kita memiliki kelebihan dibandingan rumah sakit lain dari segi keramahan pelayanan kesehatan disamping harga yang relatif lebih murah tanpa mengesampingkan profesionalisme tenaga kesehatan.

Berdasarkan hasil wawancara diatas dapat diketahui bahwa staf RS Muhammadiyah Petanahan selalu optimis bahwa RS Muhammadiyah Petanahan dapat bersaing dengan rumah sakit lain yang sejenis dan tetap menjadi prioritas bagi masyarakat sekitarnya meskipun masih memeliki beberapa kekurangan.

Persaingan antar rumah sakit dapat terjadi pada semua struktur pasar produk. Biasanya perusahaan tidak bersaing langsung dengan semua perusahaan dalam industri. Karenanya harus dilakukan identifikasi perusahaan mana yang merupakan pesaing utama.

Pengevaluasian strategi, kekuatan, kelemahan dan rencana para pesaing juga merupakan aspek kunci analisa situasi. Evaluasi ini penting untuk identifikasi pesaing yang sudah ada dan potensial. Hanya beberapa perusahaan dalam industrinya yang menyimpulkan para pesaing utama. Cravens (2000) menyatakan bahwa analisa pesaing meliputi pendefenisian arena persaingan, penganalisisan group strategis, pengambaran dan pengevaluasian tiap pesaing utama. Analisis tersebut harus menunjukan kekuatan dan kelemahan pesaing.

Setiap perubahan tentunya mengandung resiko yang harus dihadapi. Termasuk dalam rencana strategi bisnis rumah sakit yang dilakukan oleh RS Muhammadiyah Petanahan, juga terdapat resiko yang harus diperhitungkan. Berdasarkan wawancara dengan responden dapat diketahui bahwa ada beberapa responden yang tetap optimis, namun sebagian yang lain menyatakan bahwa resiko terburuk yang mungkin dihadapi adalah kembali seperti semula.

R1, R5, R6, R9: 
Yaa....paling-paling kembali seperti semula. Kayak gini lagi

R3:

Kami tidak memikirkan hal itu

R4:

Resiko utama, paling-paling ganti usaha

R7, R8:

Ya. Dan itu sudah kami perhitungkan secara matang

Hasil wawancara tersebut memberikan kesimpulan bahwa RS Muhammadiyah Petanahan sudah siap untuk menghadapi resiko apapun sebagai konsekuensi dari rencana strategi bisnis rumah sakit.

Perusahaan menggunakan pendekatan terpadu dan proaktif untuk mengelola risiko-risiko korporat. Proses manajemen risiko dilaksanakan secara terintegrasi melalui aktivitas mengidentifikasi, mengukur, memantau dan memitigasi risiko, mengkaji efektivitas pengelolaan risiko yang telah berjalan, serta memantau dan mengontrol limit eksposur, maupun mengidentifikasi dan mengevaluasi indikator-indikator risiko. Dalam proses pengambilan keputusan-keputusan strategis selama tahun berjalan juga dilakukan analisa mendalam atas ketidakpastian yang mempengaruhi relevansi dan keandalan informasi pendukung guna melindungi serta meningkatkan nilai Perusahaan.

Pengelolaan risiko di Perusahaan mencakup keseluruhan lingkup aktivitas usaha di Perusahaan, berdasarkan kebutuhan akan keseimbangan antara fungsi operasional bisnis dengan pengelolaan risikonya. Dengan kebijakan dan manajemen risiko yang berfungsi baik, maka manajemen risiko akan menjadi strategic partner bagi unit bisnis dalam mendapatkan hasil optimal dari operasi Perusahaan.

\section{SIMPULAN}

Berdasarkan hasil penelitian dan pembahasan dapat disimpulkan sebagai berikut:

Sebagian besar responden berumur diatas 35 tahun, perempuan, berpendidikan S1, lama kerja lebih dari 10 tahun, kawin, pegawai kontrak dan pernah mengikuti pelatihan Standart Asuhan Keperawatan (SAK).

Setiap staf di rumah sakit berharap agar rencana strategi bisnis rumah sakit dapat diinformasikan secara menyeluruh kepada semua staf rumah sakit melalui seminar khusus karena rumah sakit yang berkualitas menjadi harapan dan keinginan semua komponen rumah sakit.

Analisis SWOT dapat dijadikan landasan untuk merencanakan strategi bisnis rumah sakit dengan memperhatikan bahwa dilihat dari sisi analisis SWOT, rumah sakit Muhammadiyah Petanahan memiliki prospek yang menjanjikan untuk dikembangkan meskipun memiliki banyak kekurangan.

komponen-komponen rencana strategi bisnis rumah sakit secara umum sudah dipersiapkan secara matang namun belum disosialiasikan kepada karyawan di rumah sakit Muhammadiyah Petanahan. Kurangnya sosialisasi tersebut dapat diketahui bahwa hanya beberapa kepala bagian saja yang benar-benar mengetahui dan memahami rencana strategi bisnis rumah namun belum diutarakan secara rinci. Ada beberapa hal yang memang tidak dipublikasikan kepada umum seperti masalah manajemen keuangan yang kewenangan informasi diserahkan kepada bagian keuangan dan direktur rumah sakit. Saran dalam penelitian ini adalah: (1) Bagi Rumah Sakit Muhammadiyah Petanahan (2) Agar memperhitungkan semua resiko yang harus dihadapi dalam menjalankan rencana bisnis rumah sakit. (3) Dapat mensosialisasikan rencana strategi bisnis rumah sakit kepada semua komponen rumah sakit sehingga semua komponen rumah sakit dapat saling bekerja sama untuk mewujudkan rencana strategi bisnis rumah sakit. (4) Bagi responden a gar dapat mempersiapkan diri dalam melaksanakan tugas-tugasnya di rumah sakit sehingga dapat mendukung keberhasilan rencana bisnis rumah sakit.

\section{DAFTAR PUSTAKA}

1. Ardiyansah. 2007. Memahami Persaingan Bisnis, http://4rd1.wordpress.com/?s=memahami+persaingan+ bisnis\&submit. diakses 5 Juni 2010.

2. Ameta Primasari, Penilaian Standar Pelayanan Kesehatan Tingkat I Dan Fasilitasnya Bagi Peserta Jamsostek Di Medan. Skripsi

3. Assauri, Sofjan. 2004. Tantangan Pimpinan Rumah Sakit Menghadapi Paradigma Baru, Usaha-wan, XXXIII, hal. 50-55.

4. Athiyaman, A. \& R W. Robertson. 1995. Strategic Planning in Large Tourism Firms: An Empirical Analysis, Tourism Management, page: 199-205.

5. Azhary, M. Emil. 2009. Potret Bisnis Rumah Sakit Indonesia, Economic Review No. 218, Desember.

6. Barney, Jay B. 1991. Firm Resource and Sustained Competitive Advantage, Journal of Manage-ment, page: 99-120.

7. Bonn, Ingrid \& Chris Christodoulou. 1996. From Strategic Planning to Strategic Management, Long Range Planning, page: 543-551.

8. Brenes, Esteban R., Mauricio Mena, German E. Molina. 2008. Key Success Factors for Strategy Implementation in Latin America, Journal of Business research, page: 590-598.

9. Brews, Peter \& Devavrat Purohit. 2007. Strategic Planning in Unstable Environments, Long Range 
Planning, page: 64-83. Sintaasih: Knowledge Management dan Peran Strategic Partner SDM 29

10. Collis, David J. \& Cynthia A. Montgomery. 1998. Corporate Strategy - A Resource - Based Approach. Boston: McGraw-Hill.

11. Desak Ketut Sintaasih. Knowledge Management dan Peran Strategic Partner SDM: Pengaruhnya Terhadap Perencanaan Strategik dan Kinerja Organisasi (Studi pada Rumah Sakit di Bali). Skripsi

12. Fandy Tjiptono. 2006. Pemasaran Jasa. Malang: Bayumedia

13. Ferrel,O.C and D, Harline.2005. Marketing Strategy. South Western: Thomson Corporation

14. Freddy Rangkuti. 2005. Analisis SWOT Teknik Membedah Kasus Bisnis. Jakarta: PT. Gramedia Pustaka

15. Grant, Robert M. 1997. The Knowledge-Based View of the Firm: Implications for Management Practice, Long Range Planning, page: 450- 454.

16. Grant, Robert M. 1997. Contemporary Strategy analysis Concept, Techniques, and Apllication, Second Edition, Secokusumo, T. (Penerjemah). Analisis Strategi Kontemporer, Konsep, Teknik, dan Aplikasi, Jakarta: Erlangga.

17. Guiltinan, Joseph.P. 1994. Strategi dan Program Manajemen Pemasaran. Jakarta: Erlangga

18. Dwi Putra Darmawan dan Ida Bagus Widia. 2005. "Strategi PT.Nanda Bangun Nusa untuk Mempertahankan Posisi sebagai Market Leader dalam Pertamanan pada Hotel. Denpasar: Fakultas Pertanian Universitas Udayana.

19. Ircham. Machfoedz. 2008. Metodologi Penelitian. Yogyakarta. Fitramaya.

20. Jauch, Lawrence R. \& William F. Glueck. 2004. Strategic Management and Business Policy. Ninth Edition, New York: McGraw-Hill.

21. Kotler, 2000. Marketing Management. New Jersey: Prentice Hall

22. Kotler, Philip and Gary Armstrong. 2010. Principles of Marketing. Thirteenth Edition. New Jersey:Pearson Education,Inc

23. Maleong, Lexi J. 2004. Metodologi Penelitian Kualitatif. Bandung: Remaja Roskarya.

24. National Institute of Standards and Technology. 2008. Baldrige National Quality Program. Washington: US Department of Commerce.

25. Obeng, Kofi \& Isaiah Ugboro. 2008. "Effective Strategic Planning in Public Transit Systems", Transportation Research, page: 420-439.

26. Ocasio, William \& John Joseph. 2008. Rise and Fall-or Transformation? The Evolution of Strategic Planning at the General Electric Company 1940-2006, Long
Range Planning, page: 248-272. 30 Jurnal Manajemen Dan Kewirausahaan, VOL.13, NO. 1, MARET 2011: 17-31

27. Phillips, Paul A. 1996. Strategic Planning and Business Performance in The Quoted UK Hotel Sector: Results of An Exploratory Study, International Journal and Hospitality Management, page: 347-362.

28. Porter, Michael E. 1993. Competitive Advantage, Terjemahan, Jakarta: Binarupa Aksara.

29. Prawitasari, Sri Yati. 2010. Analisis Swot Sebagai Dasar Perumusan Strategi Pemasaran Berdaya Saing (Studi pada Dealer Honda Tunggul Sakti di Semarang). Fakultas Ekonomi Universitas Diponegoro Semarang

30. Reza. 2011. Analisis SWOT Di Rumah Sakit. http://semangatcalondokter.blogspot.com/2011/12/anal isis-swot-di-rumah-sakit.html

31. Robbins, Stephen P. \& Mary Coulter. 2007. Management, Eighth Edition, Terjemahan, Jakarta: Indeks.

32. Robbins, Stephen P. 2006. Perilaku Organisasi, Edisi Kesepuluh, Terjemahan, Jakarta: Erlangga.

33. Rudd, John M., Gordon E. Greenley, Amanda T. Beatson \& Ian N. Lings. 2008. Strategic Planning and Performance: Extending the Debate, Journal of Business Research, page: 99-108.

34. Satori, Djam'an dan Komariah, Aan. 2009. Metodologi Penelitian Kualitatif. Bandung : Alfabeta.

35. Suwaspodo Henry Wibowo, Pengembangan Strategi Pemasaran Rumah Sakit Berdasarkan Analisis SWOT (Studi Kasus di Rumah Sakit .Harapan Bunda Batam), Skripsi.

36. Taylor, Bernard. 1997. The Return of Strategic Planning-Once More with Feeling, Long Range Planning, page: 334-344.

37. Tjahjono, HK., 2009. Manajemen Sumber Daya Manusia, Yogyakarta, Misi Solusi Media

38. Wheelen, Thomas L. \& J. David Hunger. 2004. Strategic Management, Business Policy, Nineth Edition, New Jersey: Pearson Educational International. 